\title{
The Influence Of Human Capital On The Innovativeness Of Firms
}

\author{
Helena Santos-Rodrigues, Escola Superior de Tecnologia Gestão, Instituto Politécnico de Viana do Castelo, Portugal \\ Pedro Figueroa Dorrego, Universidade de Vigo, Pontevedra, Spain \\ Carlos Fernandez Jardon, Universidade de Vigo, Vigo, Spain
}

\begin{abstract}
Despite the importance of innovation and innovativeness within today's economy, we know little about how intellectual capital of firms can contribute to a superior innovation at the firm's level. Based on resources and knowledge-based views of firms we developed a hypothesis linking three dimensions of human capital (component of the intellectual capital) and the innovativeness of firms. As a representation of the firm's innovativeness, we consider the product, process and management innovation. Using a survey from 68 firms working on the auto components sector, established in the Northern of Spain and Northern of Portugal, we found firstly, that innovativeness has two main dimensions, perfectly differentiated, the product-process innovation and the management innovation; secondly that the human capital dimensions (formation and knowledge creation, innovative behave, and incentives to innovation) influences differently each type of innovativeness capacity. We found that the different human capital dimension influences directly, only, the product-process innovativeness. More specifically only the innovative behavior and the incentives to innovation influence the product-process innovativeness. The formation and knowledge creation dimension doesn't influence directly either the product-process innovativeness or the management innovativeness. Moreover, none of the human capital dimensions considered influence the management innovativeness directly. These results highlight the importance of human capital on innovative performance, and it allows identification of the most important dimensions that influence directly the different innovativeness capacities and more broadly, highlight the value of intellectual capital as a competitive advantage in contemporary times.
\end{abstract}

\section{INTRODUCTION}

e are moving towards a knowledge-based economy where intangible assets and investments are seen as essential elements to value creation in companies. In this sense, Knowledge-based resources have grown in importance because knowledge has become a critical ingredient for gaining a competitive advantage, particularly in the new economic landscape (Grant, 1996). The source of economic value and wealth is the creation and management of intangible assets, frequently grouped under the generic term "knowledge", "intangibles", or "intellectual capital" (Lev, 2001).

Although some attempts to measure intellectual capital have been made so far, but there is still a long way to go. Intangibles and intellectual capital (IC) have become a major issue not only for academics, but also for governments, regulators, enterprises, investors and other stakeholders during the last decade.

Knowledge is a critical input of production processes, so a firm's capability to use and combine various sources of knowledge that could transform intangible resources into value constitutes a source of competitive advantage.

The intellectual capital is increasingly considered a source of competitive advantage. Furthermore, the sustainable competitive advantage conduce to superior performances (Peteraf, 1993), and the competitive advantage based on knowledge is more sustainable (Davenport \& Prusak, 1998) because the most the firm knows, the most it can learn (Cohen \& Levinthal, 1990). 
Some firms have created a superior competitive advantage throughout a superior and unique ownership of critical intangible resources, namely, intellectual capital. While much research attention has focused on understanding how knowledge is created and distributed, little is known about performance enhancement offered by intellectual capital. The intellectual capital is the firm capacity to transform knowledge and intangible assets in wealth, building resources (L. Edvinsson, 2002), so it can be viewed as source of sustainable competitively.

In that sense, there have been made recent efforts to link intellectual capital (as a source of advantage) and innovation (as a source of competitive advantage). Some argue that intellectual capital is an innovation input (Ahuja, 2000; Cohen \& Levinthal, 1990; Nahapiet \& Ghoshal, 2002; Nonaka \& Takeuchi, 1995; Subramaniam \& Youndt, 2005; Tsai \& Ghoshal, 1998) others considerer that innovation is a result of the intellectual capital (Ahuja, 2000; Cohen \& Levinthal, 1990; Nahapiet \& Ghoshal, 2002; Nonaka \& Takeuchi, 1995; Subramaniam \& Youndt, 2005; Tsai \& Ghoshal, 1998), others that the innovation process is a knowledge management process (Ahuja, 2000; Cohen \& Levinthal, 1990; Nahapiet \& Ghoshal, 2002; Nonaka \& Takeuchi, 1995; Subramaniam \& Youndt, 2005; Tsai \& Ghoshal, 1998), or that the different innovative capacities vary on the type of knowledge needed (Cardinal, 2001).

Subramaniam and Youndt (2005), Nahapiet and Ghoshal (2002), and Ahuja (2000) had empirically connected the intellectual capital, knowledge management and the innovativeness. Nevertheless, the interest showed on the innovativeness of the firm and the factors that influence on it, there has been little results about this liaison (Wan, Ong, \& Lee, 2005).

Because intellectual capital and innovativeness are becoming more tightly couple over time, more conceptual and empirical work need to be build on. While the extant research is mainly theoretical, additional inquiry is warranted to provide a more holistic view of intellectual capital and how it affects firm performance.

Accordingly, our paper attempt to help to close the gap between intellectual capital and the innovativeness of the firm, in that sense we focus on impact of the human capital; as a relevant component of the intellectual capital jointly with the structural and relational capital and because organizational innovativeness involves the creation of new knowledge, or a novel recombination of existing knowledge, it is essentially related to human capital; on the innovativeness of the firm by addressing the following research question:

- Is human capital important in enhancing innovativeness?

\section{LITERATURE REVIEW}

The literature on knowledge management (as a strategic asset) serves as the foundations for the delineation of the firms intellectual capital (Bontis, Dragonetti, Jacobsen, \& Ross, 1999; 1996; Leif Edvinsson \& Sullivan, 1996; 1996; Roos, Roos, Dragonetti, \& Edvinsson, 1997).

Knowledge-based resources have grown in importance because knowledge has become a critical ingredient for gaining a competitive advantage, particularly in the new economic landscape (Grant, 1996)

The resource based view of the firm theory (Barney, 1991; Wernerfelt, 1984) and the subsequent knowledge-based view of the firm (Grant, 1996) provide the foundations for our assertion that intellectual capital can serve as a strategic resource that influence innovative outcomes.

The research interest on intellectual capital has been growing fast in later years, especially in firms were benefits derive majority from innovation and knowledge intensive services (Leif Edvinsson \& Sullivan, 1996). The literature consider that firms with superior intellectual resources understand, better than the competitors, how to explore, deploy, combine and configure resources and capacities on a distinct way, that gives to clients more value than the competitors (Spender \& Marr, 2005; Teece, Pisano, \& Shuen, 1997).

Innovation that may serve as the basis for competitive advantage (Khazanchi, Lewis, \& Boyer, 2007), is strongly linked to knowledge (Levinthal \& March, 1993; McGrath, 2001; Peng, Schroeder, \& Shah, 2008). Peng et al. (2008) describe the innovation-knowledge linkage as "the essence of innovation has been characterized as 
pursuit of new knowledge for discovery". Therefore, the alignment of knowledge, as an intangible resource, with the innovation strategy could enhance performance and culminate in a competitive advantage (Grant, 1996).

\section{Intellectual capital}

The management literature distinguish two different roots in knowledge research (Marr, Schiuma, \& Neely, 2004), one centred on the information and knowledge and it implication to knowledge management and other centred on knowledge as an asset manageable that permit a better firm performance. From here up come two different concepts, intellectual capital management and knowledge management.

Both perspectives rely on the management of knowledge with different focusing, but the distinction is not easy (Petty \& Guthrie, 2000). One is focused on the identification and management of the knowledge (knowledge management) and the other on the management of strategic and valuable knowledge resources (intellectual capital).

There's no consensus about the categorization of the different elements of the Intellectual Capital. Even though the debate about the components of the Intellectual Capital is still partially open, the Intellectual Capital components recognized in most of the literature are human capital, structural capital and relational capital (see Leif Edvinsson \& Malone, 1997; I.A.D.E.-C.I.C., 2003; Sveiby, 1997)

The human capital is the value of the knowledge and talent which is embodied in people who make up the organization, representing it know-how, the capacities, the knowledge, talent, competence, attitude, intellectual agility, creativity, and others (Bontis \& Fitz-enz, 2002; Davenport, Prusak, \& Wilson, 2003; Edmonson, 1999; Leif Edvinsson \& Malone, 1997; I.A.D.E.-C.I.C., 2003; Kaplan \& Norton, 1999; Roos et al., 1997).In our study we focus on the human capital and their effect (or lack thereof) on the firm innovativeness.

A group of highly motivated and uniquely capable people is a competitive advantage because they represent firm-specific resources that are important, rare and hard to duplicate. That is, firms with highly skilled and knowledgeable employees have higher levels of human capital and are more likely to create knowledge, make correct decisions and hence result in better organizational innovativeness (Hitt, Bierman, Shimizu, \& Kochhar, 2001).

Nevertheless is difficult to know how to encourage employees to contribute with their knowledge for organizational gains. People may be reluctant to share crucial knowledge for fear of losing ownership, a position of privilege or superiority. Thus, for the benefits of the organization, managers should aware an innovative attitude and incentive employed to engage an innovative attitude. They should emphasize employee capability development as well as their commitment. Human capital therefore should involve employee competencies (e.g. skills, know-how and capabilities) as well as their commitment (e.g. willingness to devote themselves to, and work for, the company).

\section{Innovativeness}

The idea that innovation is a competitive instrument essential for firm's long-term success and survival is widely recognised. Under market turbulent conditions, the firm's innovativeness is particularly important to satisfy the evolving market needs.

An innovation "is the implementation of a new or significantly improved product (good or service), or process, a new marketing method, or a new organizational method in business practices, workplace organization or external relations" (OCDE/UE, 2005, p. 33). An innovation is a product, process, marketing method, or organizational method new (or significantly improved) to the firm (OCDE/UE, 2005, p. 33).

In this sense the innovativeness of the firm has enormous potentialities, as the ability to innovate is considered as a strategic resource (Gopalakrishnan \& Damanpour, 1997, p. 22). The firms' innovativeness constitutes an antecedent of the innovative activity widely recognised in the literature (Hurley \& Hult, 1998). For instance the capability to develop new products and processes rapidly and efficiently is a powerful source of competitive advantage (Wheelwright \& Clark, 1994). 
The innovative firm is one that has implemented an innovation (product, process, marketing or organisational innovation) during the period under review (OCDE/UE, 2005, p. 34). Roos el al. (1997: 39) define innovation as an intellectual agility, tightly linked to competence; the ability to use knowledge and skills; the ability to build on previous knowledge and generate new knowledge. That means that the innovativeness involves the creation of new knowledge, or a novel recombination of existing knowledge.

So, to create new or better products, firms must reallocate resources, combine new resources or combine existing resources both inside and outside firms in new ways (Tsai \& Ghoshal, 1998). Previous studies had suggested that organizational innovativeness is closely related to human capital and organizational learning (Nahapiet \& Ghoshal, 1998). Thus, we predict the following:

$\mathbf{H}_{1}$ : $\quad$ Human capital is positively related with the innovativeness of the firm either in the product, process and management innovation output.

Hereby we predict the influence of human capital on the main innovation outputs, the product, process and management innovation. The organization innovation studies are mostly centred on one innovation output, and normally considered the product process and management typologies on an individual and independent way (Hambrick, Macmillan, \& Barbosa, 1983; Schroeder, 1990).

Figure 1 display our hypothesised relationship between human capital and the tree types of innovativeness considered. In the following sub-sections, we first briefly describe the linkage and then proceed to the formulation of the hypotheses.

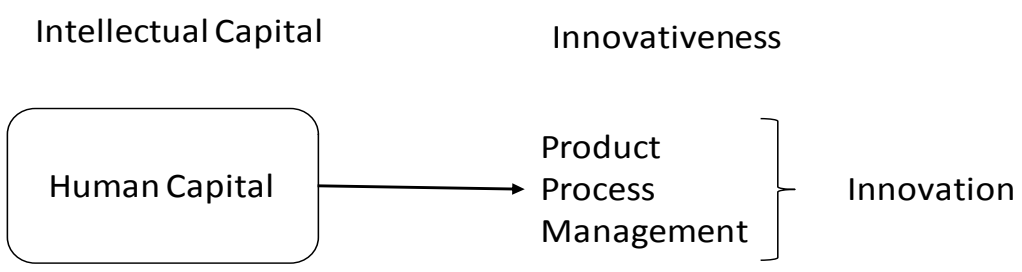

Figure 1. Hypothesized Relationships

As there aren't valid and tested scales due Intellectual capital, as well as innovativeness, we have developed new scales for human capital and innovativeness. We considered that the main human capital dimensions relevant to the firm innovativeness were the "formation and Knowledge creation" (Curado, 2006; I.A.D.E.-C.I.C., 2003; Subramaniam \& Youndt, 2005; Youndt \& Snell, 2004; Youndt, Subramaniam, \& Snell, 2004) as a representation of the knowledge of the employees due the task development, and the "innovative attitude" (Cabrita, 2006; Curado, 2006; Mouritsen, Larsen, \& Bukh, 2001; Osterloh \& Frey, 2000; Ravichandran, 2000) as the commitment and willingness of the employees and employers to innovate, "creativity" (Curado, 2006; Davenport et al., 2003; I.A.D.E.-C.I.C., 2003; Mouritsen et al., 2001; Subramaniam \& Youndt, 2005; Youndt \& Snell, 2004; Youndt et al., 2004) representing the willingness, support and value of the creativity of the employes; we also considered the "incentive to innovativeness" (Curado, 2006; I.A.D.E.-C.I.C., 2003; Ravichandran, 2000; Shelton, Davila, \& Brown, 2005; Wan et al., 2005) as the personal and material incentives regarding an innovative behavior of the employees.

We relied on three performance measures of the innovativeness: the product, process and management innovation (Ahuja, 2000; Davenport et al., 2003; Hii \& Neely, 2000; Molina-Palma, 2004, p. 175; Ravichandran, 2000). On our analysis we considered the relative innovation, meaning that an innovation is considered new if it is new to the firm, and nevertheless it isn't new to the world or industry. 


\section{METHODS}

\section{Sample and data collection}

We tested the hypothesis using a survey data collected in 2007 from firms registered on the main and most representative associations of the sector in Spain and North Portugal. Those associations that meet the requires were "Fundación Clúster de Empresas de Automoción de Galicia" (CEAGA) in representation of the northern Spain (Galicia) firms, plus the "Associação de Fabricantes de Industria Automóvel" (AFIA) as representative of companies in North Portugal.

We targeted 135 companies, 66 from Galicia and 69 from the northern of Portugal. While obtaining a sample of significant linkage of the intellectual capital as a strategic resource and it effect on the innovativeness would allow more comprehensive understanding of the phenomenon, we relied on upper managers as key expert informants - an established practice in organizational research (Huber \& Power, 1985)- and because are those whom are aware of the strategic choices.

The survey was constructed in Portuguese and Spanish, while the firms were in to different countries. To assure the language consistence of the survey it was tested with some scholars and specialist of the sector. The data collection took place in June 2007 via regular mail to 135 companies. Each participation request included a description of the study, a statement of confidentiality, and a way back envelop pre-stamped.

We received 68 responses, for a response rate of 50,37\% percent. Of the responses, 45 came from the Galicia firms, while 23 were obtained from the Portuguese firms. Of the 68 firms responding, we were able to obtain archival performance data equivalent, thus 68 was our effective sample size.

To assess the randomness of the sample we have done a not parametric test adjustment $X^{2}$-sample population. This test is applied to a sample in which the variable has two or more categories, comparing the frequencies with the frequencies shown by the population. We consider as a classification variable the location (Galicia and Northern Portugal) and the respective district areas: Coruña, Lugo, Ourense, Pontevedra and Aveiro, Braga, Porto, Viana, Vila Real, respectively. It proved the value of 8.0522, see the tables of chi-square with 7 degrees of freedom we get a tail probability of 0.3280 , which is larger than a significance level of 0.05 , which accepts the null hypothesis of equality between the two frequencies. Therefore we verify a good fit of the sample to the studied population.

\section{Data analysis}

We continue with the exploratory data analysis to verify the existence of outliers and missing values. Respect to outliers, once data are on a Likert scale of five points, no comments could be done regarded the outlier. As for the missing values we choose to eliminate the responses of two items with large number of items omitted, and whose elimination does not influence the outcome of the investigation.

We proceed with a preliminary data analysis; analyze the descriptive statistics and the representation through histograms.

Then we verify the reliability or consistency of the construct, or the extent to which the indicators converge, or are correlated with each other to reflect a given construct. To this end, we used to measure the convergent validity, Cronbach's alpha coefficient. Thus, for each of the items was conducted to check the reliability of the scale, excluding those items that does not give good levels of reliability.

Table 1: Initial model constructs

\begin{tabular}{|l|c|c|}
\hline \multicolumn{1}{|c|}{ Constructs } & $\mathbf{N}^{\mathbf{0}}$ ítems & $\boldsymbol{\alpha}$ de Cronbach \\
\hline Human Capital (CH) & 16 &, 750 \\
\hline Innovativeness (CI) & 6 &, 688 \\
\hline
\end{tabular}


We can see that there is an acceptable degree of reliability of the constructs the Cronbach's alpha of our constructs is above 0.6. Being the smaller, but earned, the innovative capacity (0688).

After analyzing the reliability of the construct, we did a factor analysis of Principal Components to see if items were grouped in the form originally proposed, or whether the conceptualized dimensions are consistent with the dimensions found. So, we explore the variables and statistically analyze the subsequent results. For this, we set a cut-off of 0.30 and retained factors explain at least $50 \%$ of the items. The factors were subjected to a Varimax rotation with Kaiser Normalization.

Once the data reduction through factor analysis of principal components, for all items of human capital, it is verified that the KMO indicates a reasonable correlation between the variables $(\mathrm{KMO}=0,710)$.

\section{Human Capital}

The principal component analysis proved that the original 16 items are explained by $53,277 \%$ at 3 common factors obtained through a rotation Varimax with Kaiser Normalization converged in 5 interactions.

The first factor is the training, talent and skills of employees and value the creativity and potential they represent for the company. It also represents the role of the innovative company in employee satisfaction with the company. Therefore we call this as "Formation and knowledge creation $(\mathrm{CH})$. The second factor is the innovative attitude of the company, managers and employees. First, to what extent the company facilitates the emergence of ideas and development of the invention and how innovation is a core principle of the company. Second, managers and their appetite for change and willingness to innovate as well as its ability to influence employees to innovate. Finally, it includes innovative by employees and their contribution to the value of the organization. Thus, we call this factor "innovative attitude" $(\mathrm{CH})$. Finally, the third factor represents the extent to which employees show willingness to innovate and the company supports the initiative. We call this construct as "Incentive for Innovation" $(\mathrm{CH})$.

Table 2: H.C. construct analysis

\begin{tabular}{|c|c|c|c|c|c|}
\hline \multicolumn{2}{|r|}{ Constructs } & \multirow{2}{*}{$\begin{array}{c}\text { Var. acum. Expl. (\%) } \\
53,277\end{array}$} & \multirow{2}{*}{$\begin{array}{r}\text { KMO } \\
0,710\end{array}$} & \multicolumn{2}{|c|}{ Bartlett's test } \\
\hline 祍 & $\begin{array}{l}\text { "formation and Knowledge creation" } \\
\text { "innovative attitude" } \\
\text { "incentive to innovativeness" }\end{array}$ & & & $\begin{array}{c}\mathrm{Chi}^{2}= \\
429,703\end{array}$ & $\begin{array}{c}\text { Sig. } \\
0,000\end{array}$ \\
\hline
\end{tabular}

Have been created 3 constructs: CH_ATITUDE, CH-FORMACIÓ; CH_INCENT. We saw that with the principal component factor analysis the items are grouped differently than originally proposed. This situation is usual considering the exploratory statistical method used.

\section{Innovativeness}

Factorial analysis of main components of the innovativeness indicates a reasonable correlation between the variables $(\mathrm{KMO}=0536)$. The Bartlett test of sphericity's has an associated level of significance of 0000 , then there is some correlation between variables. Both tests allow the continuation of the factorial analysis. The matrix of components shows that the 6 variables are explained $67,562 \%$ by 2 common factors, obtained through a rotation Varimax with Kaiser Normalization converged in 3 to interactions.

The first factor relates the development and introduction of innovative management and its significant contribution to improving the company's profits. We call it the "Innovative Capacity Management (CI_Gestion). The second factor concerns the introduction of product innovations and significant contribution to improving the company's profits, the introduction of significant innovations in process and its importance in reducing costs and other improvements. We called it "Innovative product and process Capacity (CI_Prod_proce). 
Table 3: C.I. construct analysis

\begin{tabular}{|c|c|c|c|c|c|}
\hline \multicolumn{2}{|c|}{ Constructs } & Var. acum. Expl. (\%) & KMO & \multicolumn{2}{|c|}{ Bartlett's test } \\
\hline & & & & & \\
\\
\hline
\end{tabular}

As for human capital the items, due the exploratory analysis, were grouped differently than the initial proposal.

\section{RESULTS}

For the data analysis we did a regression analysis with the variables of human Capital and Innovative product and process capacity, selecting the $B$ 's with values that excess 0,200 , it demonstrates the existence of robust relationships between the constructs.

Table 4 Regression analysis

Coeffi cients, ${ }^{\mathrm{a}, \mathrm{b}}$

\begin{tabular}{|c|c|c|c|c|c|c|}
\hline \multirow[b]{2}{*}{ Model } & & \multicolumn{2}{|c|}{$\begin{array}{l}\text { Unstandardized } \\
\text { Coeff icients }\end{array}$} & \multirow{2}{*}{$\begin{array}{c}\text { Standardized } \\
\text { Coeff icients } \\
\text { Beta }\end{array}$} & \multirow[b]{2}{*}{$t$} & \multirow[b]{2}{*}{ Sig. } \\
\hline & & $B$ & Std. Error & & & \\
\hline 1 & $\begin{array}{l}\text { CH-ATITUD } \\
\text { INNOVADORA }\end{array}$ & ,492 & ,106 & ,492 & 4,628 & ,000 \\
\hline 2 & $\begin{array}{l}\text { CH-ATITUD } \\
\text { INNOVADORA }\end{array}$ & ,492 & ,099 & ,492 & 4,957 & ,000 \\
\hline & $\begin{array}{l}\text { CH-INCENTIVOC } \\
\text { INNOVACION }\end{array}$ & ,327 & ,099 & ,327 & 3,296 & ,002 \\
\hline
\end{tabular}

a. Dependent Variable: CI-INNOVACION DE PRODUTO Y PROCESO

b. Linear Regression through the Origin

Considering the results obtained with the multiple linear regression analysis, we note that Human Capital variables with the positive and significant effect on the Innovative product and process capacity are the innovative attitude (0,492 with sig. 000) and incentives to innovate (0,327, with sig. 0002). We didn't found any relation between Formation and Knowledge management variable and Innovative product and process capacity.

We didn't found a direct relationship between formation and knowledge creation $(\mathrm{CH})$ with any of the innovative capacities considered. These dimensions are related only by proxy. Nonala and Takeuchi (1995) noted that knowledge is the essence of innovation, so in that sense this result is surprising because the formation and knowledge are factors mostly considered in the literature regarding the management of knowledge assets.

The innovative process to create or adopt innovations seams to be inseparable from human creativity, moreover, in a constantly changing market, knowledge and employees skills are very important in the design of new products and services (Greenley \& Foxall, 1998). But our study doesn't support this consideration. This result may be a consequence of how the construct where built.

The innovative attitude in our results has a very important role. This result is in line with the idea that the innovative firm can play an important role in employee satisfaction (Curado, 2006). Besides the importance of the innovative attitude of the company is relevant the innovative attitude of collaborators. Much of the value of a 
company depends on the innovative attitude of his employees (Curado, 2006) it can be enhanced through financial incentives (Osterloh \& Frey, 2000).

Also the incentives to innovate $(\mathrm{CH})$ are an important contribution to the products and process innovativeness. It is possible to enrich the work environment and thereby to encourage creativity and learning of the workers. The company that facilitates the emergence of new ideas and development of the inventive (I.A.D.E.C.I.C., 2003) and that does not penalize innovation errors committed by employees, which encourages employees to find creative solutions, new ways of doing things and functioning of labor (Mouritsen et al., 2001; Ravichandran, 2000 ) is more conducive to innovation.

\section{CONCLUSION}

In this study we found several important contributions for theory. We identify theoretical implications of our study, mainly in two subject areas: the literature of Intellectual Capital and Innovation literature.

For the literature of intellectual capital, this work produces two major contributions. The first contribution is that we found some relevant dimensions of Intellectual Capital for the innovative capacity of the company. The intellectual capital is accepted as strategic factors that include resources, skills and capabilities that act and interact to create value. Human capital is considered a central element of the company. Some authors suggest that human capital is the central element of intellectual capital (Bontis, 1998; Bontis et al., 1999; Bontis \& Girardi, 2000; Leif Edvinsson \& Malone, 1997; Stewart, 1998; Sveiby, 1997). Our study confirms that human capital is important for the innovative capacity of the company, but in this research the Human Capital is not directly related to the management Innovativeness.

The second contribution is to the innovation literature and concerns the several innovative capabilities found in this study. First we saw that the Management innovativeness and the product, process innovativeness capacities are differentiated which consequently require different knowledge. Furthermore we saw that the product and process innovativeness are coincident and refer to the same phenomenon. We found that a new product innovation needs a new production process, which justifies that the product process innovativeness represents a same capacity. So there is a need to adjust the production process of a product innovation. It means that these two types of innovation are intrinsically related.

The developed model validated the research problem and led to the following general conclusions:

- The first conclusion is that the Intellectual Capital influences the innovativeness of the companies producing components for the automotive sector within the European region of Galicia and Northern Portugal;

- The second conclusion confirms that the elements of intellectual capital influence the innovative capacity differently. This is the greatest contribution of this work for theory and management. We found that the products and processes innovation is influenced directly and on an important way by the Human Capital.

To sum up, the results of our study helps close the gap between what we know and what we need to know about the effects of human capital on firm innovativeness and permits to support partly our $\mathrm{H}_{1}$, that Human capital is positively related with the innovativeness of the firm either in the product, process and management innovation output. We didn't found a direct relation of human capital and management innovativeness.

Further study should be done in two senses. to provide further evidence of our conclusions testing our model in different sectors or even doing a multisector test. Even more, further tests of our model, concerning the liaisons not found such as the relation between human capital and management innovation should be done. 


\section{REFERENCES}

1. Ahuja, G. (2000). Collaboration networks, structural holes, and innovation: A longitudinal study. Administrative Science Quarterly, 45(3), pg. 425-455.

2. Barney, J. (1991). Firm Resources and sustained competitive advantage. Journal of Management, 17(1), 99-120.

3. Bontis, N. (1998). Intellectual capital: an exploratory study that develops measures and models. Management Decision, 36(2), 63-76.

4. Bontis, N., Dragonetti, N. C., Jacobsen, K., \& Ross, G. (1999). The knowledge Toolbox: A Review of Tools Available to Measure and Manage Intangible Resources. European Management Journal, 17(4), 391-402.

5. Bontis, N., \& Fitz-enz, J. (2002). Intellectual capital ROI: A casual map of human capital antecedents and consequents. Journal of Intellectual Capital, 3(3), 223-247.

6. Bontis, N., \& Girardi, J. (2000). Teaching knowledge management and intellectual capital lessons: an empirical examination of Tango simulation. Journal of Technology Management, 20(5/6/7/8), 545-555.

7. Brooking, A. (1996). Intellectual capital. Core asset for the third millennium enterprise $\left(1^{\text {st }} \mathrm{ed}.\right)$. London: International Thomson Business Press.

8. Cabrita, M. R. (2006). Capital Intelectual e Desempenho Organizacional no Sector Bancário Português. Unpublished Tese de Doutoramento em Gestão, Universidade Técnica de Lisboa, Lisboa.

9. Cardinal, L. (2001). Technological innovation in the pharmaceutical industry: the use of organizational control in managing research and development. Organization Science, 12(1), 19-36.

10. Cohen, W. M., \& Levinthal, D. A. (1990). Absorptive Capacity: A New Perspective On Learning And Innovation. Administrative Science Quarterly, 35(1), 128-152.

11. Curado, C. M. M. (2006). O efeito mediador das estratégias de gestão do conhecimento entre componentes do Capital Intelectual: Um estudo realizado na industria bancária portuguesa. Unpublished Tese de Doutoramento em Gestão, Universidade Técnica de Lisboa, Lisboa.

12. Davenport, T. H., \& Prusak, L. (1998). Working knowledge-how organizations manage what they know. Boston, Massachusetts: Harvard Business School press.

13. Davenport, T. H., Prusak, L., \& Wilson, H. J. (2003). Who's bringing you hot ideas and are you responding? Harvard Business School Press, 81(2), 58-64.

14. Edmonson, A. (1999). Psychological safety and learning behaviour in work teams. Administrative Science Quarterly, 44(2), 350-383.

15. Edvinsson, L. (2002). What is IC? www.unic.net. Retrieved 2008

16. Edvinsson, L., \& Malone, M. S. (1997). El Capital Intellectual: Cómo Identificar y calcular el valor de los recursos intangibles de su empresa: Gestión 2000.

17. Edvinsson, L., \& Sullivan, P. (1996). Developing a Model for Managing Intellectual Capital. European Management Journal, 14(4), 356-364.

18. Gopalakrishnan, S., \& Damanpour, F. (1997). A Review of Innovation Research in Economics, Sociology and Technology Management. Omega, 25( I), 15-28.

19. Grant, R. M. (1996). Toward A Knowledge-Based Theory Of The Firm. Strategic Management Journal (1986-1998), 17( Winter Special Issue), 109-122.

20. Greenley, G. E., \& Foxall, G. R. (1998). External moderation of associations among stakeholders orientations and company performance. International Journal of Research in Marketing, 15(1), 51-69.

21. Hambrick, D. C., Macmillan, I. C., \& Barbosa, R. R. (1983). Business unit strategy and changes in product R\&D budgets. Management Science, 29, 757-769.

22. Hii, J., \& Neely, N. (2000). Innovative capacity of firms: on why some firms are more innovative than others. Paper presented at the 7th International Annual EurOMA Conference 2000, Ghent.

23. Hitt, M. A., Bierman, L., Shimizu, K., \& Kochhar, R. (2001). Direct and moderating effects of human capital on strategy and performance in professional service firms: a Resource-based perspective. Academy of Management Journal, 44(1), 13-28.

24. Huber, G., \& Power, D. (1985). Retrospective reports of strategic-level managers: guidelines for increasing their accuracy. Strategic Management Journal, 6(2), 171-180.

25. Hurley, R. f., \& Hult, G. T. M. (1998). Innovation, market orientation, and organizational learning: an integration and empirical examination. Journal of Marketing, 62(3), 42-54. 
26. I.A.D.E.-C.I.C. (2003). Modelo Intellectus: medición y gestión del capital intelectual (Documentos Intelectos). Madrid.

27. Kaplan, R. S., \& Norton, D. (1999). Cuadro de Mando Integral (The Balanced Scorecard). España: Gestión 2000.

28. Khazanchi, S., Lewis, M. W., \& Boyer, K. K. (2007). Innovation-supportive culture: the impact of organizational values on process innovation. Journal of Operations Management, 25(4), 871-884.

29. Lev, B. (2001). Intangibles: Medicion, Gestion e informacion (M. García-Ayuso, Trans. 2 ed.). Barcelona: Ediciones Deusto.

30. Levinthal, D. A., \& March, J. G. (1993). The myopia of learning. Strategic Management Journal, 14(8), 95-112.

31. Marr, B., Schiuma, G., \& Neely, A. (2004). Intellectual capital defining key performance indicators for organizational knowledge assets. Business Process Management Journal, 10(5), 551-569.

32. McGrath, R. G. (2001). Exploring learning, innovative capacity, and managerial oversight. Academy of Management Journal, 44(1), 118-131.

33. Molina-Palma, M. A. (2004). A capacidade de inovação como formadora de valor: análise dos vetores de valor em empresas brasileiras de biotecnologia. Unpublished, Universidade de São Paulo, São Paulo.

34. Mouritsen, J., Larsen, H. T., \& Bukh, P. N. (2001). Valuing the future: Intellectual capital supplements at Skandia. Accounting, Auditing \& Accountability Journal, 14(4), 399-422.

35. Nahapiet, J., \& Ghoshal, S. (1998). Social capital, intellectual capital, and the organizational advantage. Academy of Management Review, 23(2), 242-266.

36. Nahapiet, J., \& Ghoshal, S. (2002). Social capital, intellectual capital, and the organizational advantage. In C. W. Choo \& N. Bontis (Eds.), The Strategic Management of Intellectual Capital and Organizational Knowledge (pp. 673-698). New York: Oxford University Press.

37. Nonaka, I., \& Takeuchi, H. (1995). The knowledge Creating Company. How Japanese Companies Create The Dynamics of Innovation ( $1^{\text {st }}$ ed.). London: Oxford University Press.

38. OCDE/UE. (2005). Oslo Manual OCDE.

39. Osterloh, M., \& Frey, B. S. (2000). Motivation, knowledge transfer, and organizational forms. Organization Science, 11(5), 538-550.

40. Peng, D. X., Schroeder, R. G., \& Shah, R. (2008). Linking routines to operation capabilities: a new perspective. Journal of Operations Management, 26(6), 730-748.

41. Peteraf, M. A. (1993). The cornerstones of competitive advantage: a resource-based view. Strategic Management Journal, 14(3), 179-191.

42. Petrash, G. (1996). Dow's Journey to a knowledge value management culture. European Management Journal, 14(4), 365-373.

43. Petty, R., \& Guthrie, J. (2000). Intellectual capital literature review measurements, reporting and management. Journal of Intellectual Capital, 1(2), 155-176.

44. Ravichandran, T. (2000). Redefining organizational innovation: towards theorical advancements. The Journal of Hight Technology Management Research, 10(2), 243-274.

45. Roos, J., Roos, G., Dragonetti, N. C., \& Edvinsson, L. (1997). Intellectual capital: navigating in the new business landscape. London.

46. Schroeder, D. M. (1990). A dynamic perspective on the impact of process innovation upon competitive strategies. Strategic Management Journal, 11, 25-41.

47. Shelton, R., Davila, T., \& Brown, P. (2005). The Seven Rules Of Innovation. Optimize, 4(8), 51-56.

48. Spender, J.-C., \& Marr, B. (2005). Knowledge-based perspective on Intellectual Capital. In B. Marr (Ed.), Perspectives on intellectual capital (pp. 183-195). Oxford: Elsevier Butterworth-Heinemann publications.

49. Stewart, T. А. (1998). La nueva riqueza de las organizaciones: el capital intelectual ( $2^{\mathrm{a}}$ ed.). Barcelona.

50. Subramaniam, M., \& Youndt, M. A. (2005). The influence of intellectual capital on the types of innovative capabilities. Academy of Management Journal., 48(3), 450-463.

51. Sveiby, K.-E. (1997). Capital intelectual la nueva riqueza de las empresas, como medir y gestionar los activos intangibles para crear valor ( $1^{a}$ edición ed.). Barcelona: Gestion 2000.

52. Teece, D. J., Pisano, G., \& Shuen, A. (1997). Dynamic capabilities and strategic management. Strategic Management Journal (1986-1998), 18(7), 509-533.

53. Tsai, W., \& Ghoshal, S. (1998). Social capital and value creation: The role of intrafirm networks. Academy of Management Journal, 41(4), 464-478. 
54. Wan, D., Ong, C. H., \& Lee, F. (2005). Determinants of firm innovation in Singapore. Technovation, Vol. 25, 261-268.

55. Wernerfelt, B. (1984). A resource-based view of the firm. Strategic Management Journal, 5(2), 171-180.

56. Wheelwright, S. C., \& Clark, K. B. (1994). Accelerating the design-build-test cycle for effective product development. International Marketing Review, 11(1), 32-46.

57. Youndt, M. A., \& Snell, S. A. (2004). Human Resource Configurations, Intellectual Capital, and Organizational Performance. Journal of Management Studies, XVI( 3), 337-360.

58. Youndt, M. A., Subramaniam, M., \& Snell, S. A. (2004). Intellectual Capital Profiles: An Examination of Investments and Returns. Journal of Management Studies, 41(2), 335-361. 
NOTES 